\title{
Landscape of visions: the Ekolsund manorial estate, Sweden
}

\author{
Åsa Ahrland \\ Department of Urban and Rural Development, Swedish University of Agricultural Sciences, \\ Uppsala, Sweden
}

\begin{abstract}
Parks and gardens are characterized by constant change and the need to be continuously managed and recreated. Over time, layers of history are built up, reflecting artistic and human ideals, socio-economic factors, technology and practices from different periods. Designed landscapes are archives and often have significant levels of biodiversity. One example is the Ekolsund manorial estate in Sweden, laid out in the seventeenth century in a large-scale project. Buildings, gardens and parks formed part of an overall architectural composition, where representation and display were key elements. With its audacity and grandeur, Ekolsund represents a new approach to landscape design in Sweden. The later development includes an early attempt by King Gustavus III to create landscape gardens and, during the era of capitalist owners, the planting of arboreta. Despite favourable conditions for a restoration of the seventeenth-century designed landscape, this paper argues for a holistic approach, where visions and actions of different agents - that together have shaped Ekolsund - are the foundation. Where cultural and natural values complement each other, requiring collaboration between research disciplines and the cultural heritage and nature conservation sectors.
\end{abstract}

Keywords: Designed landscapes, conservation, layers of history, cultural and natural values, Sweden

\section{Introduction}

Gardens and parks are characterized by constant change and the need to be managed and continuously recreated; this is their very essence. In order to come into being and survive, a designed landscape needs to be defined, planned, shaped, controlled and renewed again and again in a constant process. Over time, gardens and parks build up several layers of history that reflect artistic and human ideals as well as socio-economic factors, technology and practices from different periods. As a consequence, gardens and parks do not only constitute a multifaceted cultural heritage, they are archives in themselves, from which knowledge can be obtained. They generally have significant levels of biodiversity, protected and unprotected, which contribute to their value from a sustainability perspective.

The conservation of gardens and parks has mainly been concerned with keeping and recreating aspects of landscape architecture and horticulture, while natural values and biodiversity have been less in focus. Is it possible, or even desirable, to widen the scope in order to preserve and develop cultural and natural values, so they do not compete, but work together and enrich such a landscape? Does this complexity represent a problem, 


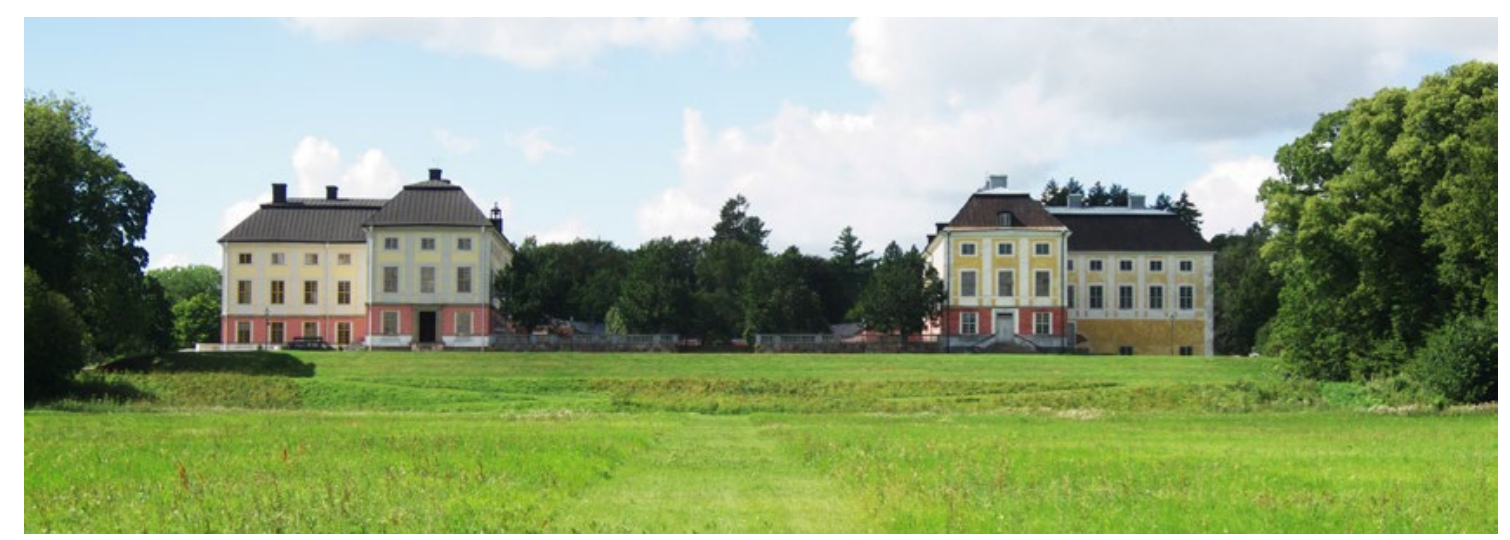

Figure 1: Present day Ekolsund manorial estate with its sense of past grandeur. Creative Commons CC0 1.0 Universal Public Domain Dedication.

or is it an opportunity to create interesting multidimensional landscapes with different values and narratives? This study focuses on the Ekolsund manorial estate, situated 40 $\mathrm{km}$ northwest of Stockholm in Sweden (Fig. 1) and the significance of the visions and actions of its occupants over time in relation to the present landscape and its conservation and development. It is suggesting an approach, but is not concentrating on the actual management of the site. The methodology is a survey based on historical maps, written and oral sources, imagery and fieldwork.

Despite later alterations and a need to simplify the gardens and the grounds, Ekolsund is still one of the best-kept seventeenth-century designed landscapes in Sweden. However, as a result of lacking resources, changing visions and neglect over time, the Ekolsund manorial estate can also be described as a ruin with a sense of past grandeur. Instead of a manicured formal pleasure garden with well-defined structures, Martagon Lilies spread and bloom in abundance in the meadows, sheep graze in the woodlands that were once intended for bosquets and the waterworks are visible but dilapidated structures. Many of the seventeenthcentury lime trees remain in the avenues as giant witnesses of the past. Their materiality is an important document of the introduction of Dutch lime in Sweden and even in very poor condition, they are habitats for endangered species. In order to understand the situation at Ekolsund and what we can learn from the site, it is vital to comprehend its history and the ideas it has been subject to.

\section{Transforming the estate of Ekolsund}

The name Ekolsund appears for the first time in 1307 when two letters were sent from the estate by two Swedish dukes, Erik and Valdemar, the younger brothers of Birger, the King of Sweden. At that time the actual settlement was situated on a small island off the shore of Lake Mälaren. The location was characteristic of a Swedish medieval fortified manor: secluded, easy to defend and with direct access to the important waterways. Remnants of a stone cellar and a moat still remain on the site in what later became a peninsula (Björklund 2014: 247). Over the centuries, Ekolsund passed through the hands of members of the Swedish elite and in 1540 became the property of Gustavus I. The King often visited the estate which at that time comprised of 30 homesteads but was soon expanded (Björklund 2014: 34, 242). During 
this period, the garden of Ekolsund was probably situated by the water, a little further south from the manor as indicated on a map from 1688. We know that the garden produced a fair amount of apples and pears and that the harvest from the home farm Segersta also included hemp, peas, beans as well as cabbage for sauerkraut (Björklund 2014: 243). Supplies such as beer, bread, butter, sheep, calves, fresh fish, and cereals were delivered to the court in Stockholm (Björklund 2014: 167, 245-246).

Ekolsund remained in royal possession until 1624, when it was donated, together with the nearby Segersta estate, by Gustavus Adolphus to his cousin Åke Tott (1598-1640). Tott was pursuing a successful military career and would end up as a field marshal. After the King's death in 1632, Tott, who had contracted bad health during the many years in the army, withdrew from war service. He settled down in Ekolsund and repaired and updated the main building. Inventories from 1634 show that the field marshal and his family seemed to live in style with costly interiors (Söderberg 1967: 143), some of which was probably brought home from the war, while others were part of Tott and his wife's (Baroness Sigrid Bielke) inheritance.

However, Tott was not content with the state of affairs at Ekolsund. He had his mind set on transforming his only estate in Sweden - most of his possessions were located in Finland, then a part of the Swedish realm - into something on a much grander scale. By acquiring land close by on the north side of Lake Mälaren, Tott created a large estate where the centre (Fig. 2), a new manor surrounded by gardens and hunting grounds, was to be built

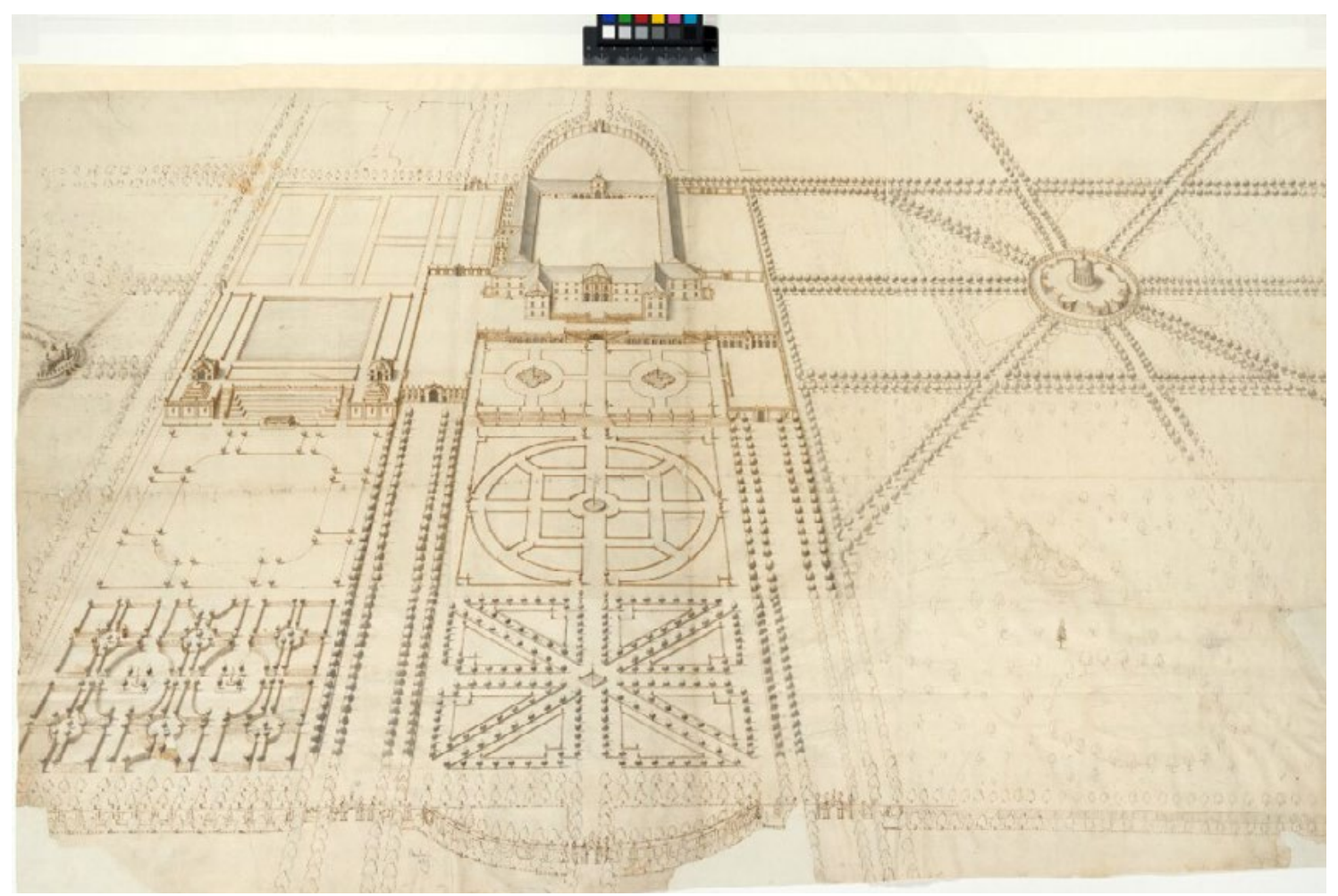

Figure 2: The most skillful architects in the country were engaged to create a new scheme for Ekolsund. Jean de la Vallé's grand perspective from ca 1652. Photograph by Cecilia Heisser/Nationalmuseum. Public Domain Mark 1.0 (CC PD). 
further north. The French architect and engineer Simon de la Valle (d. 1642), at the time working for Frederick Henry, Prince of Orange, was commissioned for the job. Several Dutch master masons were also employed (Noldus 2005:177). De la Vallé seems to have suggested a long main building with protruding pavilions and a large forecourt with lower buildings. However, of the extensive house, only the northern part was built during Åke Tott's time. (Ellehag 2003: 15, 119-121). A new garden was laid out with a gazebo and regular beds, some of which, according to the accounts, were planted with flowers and boxwood in various decorative patterns (Ellehag 2003: 120; Karling 1931: 431). When Åke Tott died in 1640 due to his poor health, all the building activities came to a stop. An inventory from 1651 mentions that the garden, at that point, contained a large number of fruit trees as well as various vegetables planted in beds It also indicates parterres with roses and boxwood and ponds - a decorative, but also a necessary element in this marshy area. The park held 52 deer and was equipped with a cottage, probably for the park keeper (Karling 1931: 431).

After mediation with Queen Christina, Ảke Tott's son Clas Tott (1630-1674) agreed in 1652 to give up Ekolsund in replacement of another estate. The new owner was the national treasurer Magnus Gabriel De la Gardie, a keen builder and garden enthusiast. In order to develop and update Ekolsund further, the then leading architect in the country, Jean de la Vallé (1624-1696), the son of Simon de la Vallé, was commissioned to draw a plan. However, De la Gardie fell out of favour with the queen and the estate was returned to Clas Tott

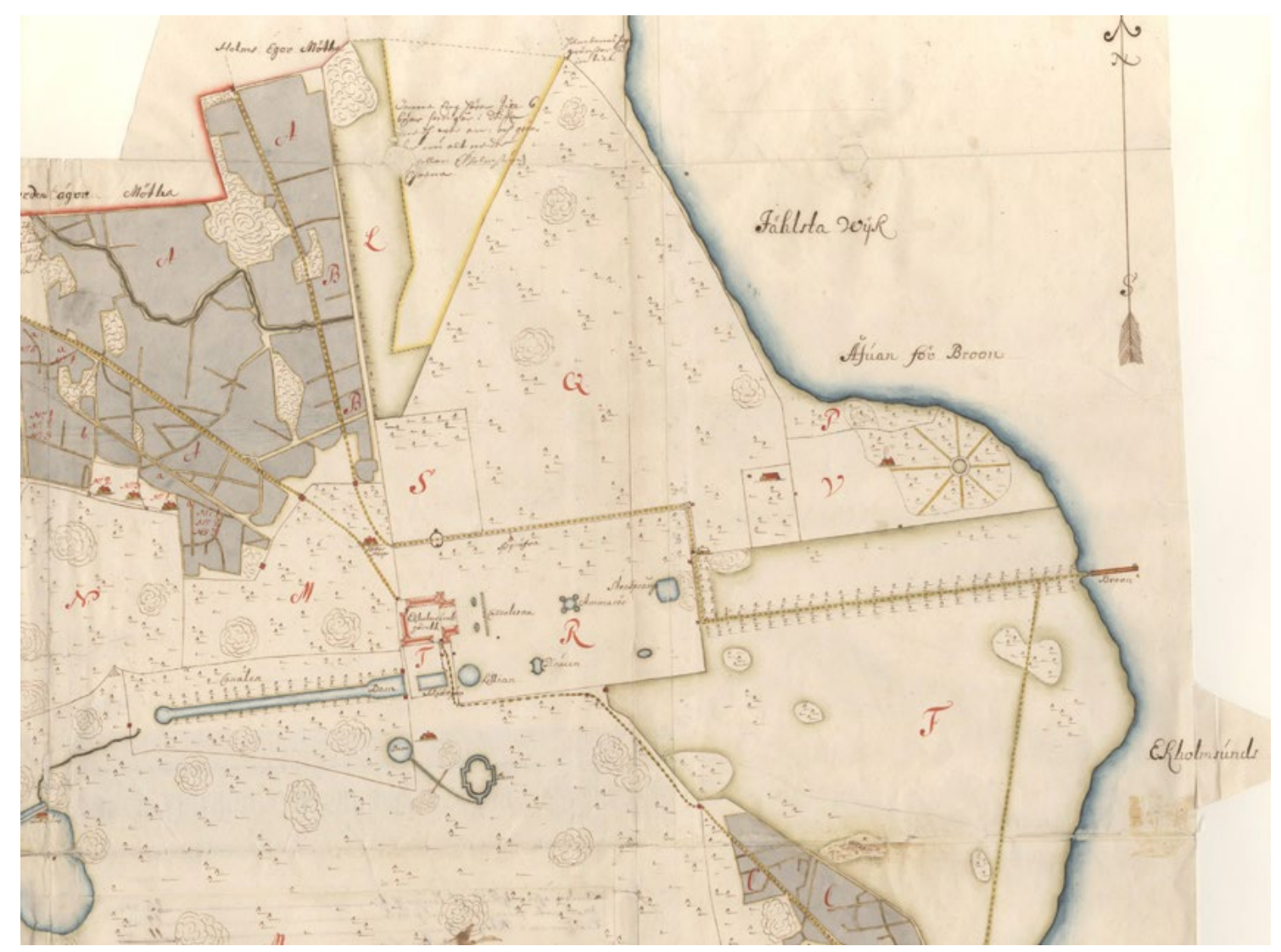

Figure 3. The 1688 surveyor map of Ekolsund shows that many of the waterworks were then in place. Modified (detail). LSA A15 Lantmäteriet (61-62). 
after only a couple of years. Tott continued the collaboration with Jean de la Valle with the intention to create the grandest and most splendid manor and designed landscape in Sweden at the time (Fig. 2). In the 1660s, de la Vallé was replaced by his rival Nicodemus Tessin the Elder (1615-1681) in the project. Tessin's plans were based on de la Vallés concept, probably a consequence of the fact that the construction work with the southern part of the house, gardens and parks were well on its way (Olausson 1997:172). The scheme for Ekolsund, particularly the later plans by Tessin, was on par with other prestigious estates in Europe and in tune with the development in France. Buildings, gardens and parks would form part of the overall architectural composition of the estate, where representation and display would be key elements. The French experience was very much first-hand. Jean de la Vallèe and Clas Tott had studied in Paris and Nicodemus Tessin the Elder made an extensive European study tour, which included France, in the early 1650s. Clas Tott also spent a considerable amount of time as a diplomat in Paris.

The many plans, with various alterations produced over the years, are a testimony to the fact that the project was not easy to pull through. The scheme was never to be completed. The central section of the house was never built, only the two large L-shaped side buildings. Bosquets were planted in the pleasure garden, but only on one side of the parterres, while on the other side the rocky terrain with spruce remained, without being turned into cultured nature. The gardens were also intended to stretch further south, but as the construction work was only partially carried out, some of the waterworks were situated in a large area of wooded pasture land, referred to as "The Cow Pasture" on a 1725 map (Lantmäteristyrelsens arkiv B29-2:1) (Fig. 5).

Despite the imperfections, with its scale, audacity and grandeur articulated in long axes, different levels and display of waterworks, Ekolsund represents a completely new approach to landscape design in Sweden. Water in the form of fountains, cascades, ponds and a 570-metre long canal played a major part in the gardens, and some waterworks such as the cascades were novelties at the time (Fig. 3). These important prerequisites were a rich supply of water to the site and skilled specialists, fontaineurs, knew how to construct the complicated system of pipes and reservoirs in order to create self-pressure and supply the many water features. The French fontaineur Pierre Grandmaison was leading the work, but the Swede Erik Hoffwenius was also involved. The correspondence between Hoffwenius and his employer shows how closely Clas Tott followed the work and also gives an insight into the techniques used and the problems that had to be solved (Dahl 1995: 237-238).

An important characteristic at Ekolsund were the double avenues, lime trees planted in four rows, underlining the main axis and connecting the buildings, gardens and the surrounding landscape with Lake Mälaren beyond. The redesign of the landscape would also include kitchen gardens, orchards and a nursery. Clas Tott had a keen interest in garden design and gardening. He would purchase garden books as well as decorative elements for his gardens from the Swedish agent Peter Trotzig in Amsterdam. In 1664, Trotzig would, for instance, mediate not only flower pots in various sizes but several statues including "1 Greek Venus, 1 Apollo, 1 Mercury and 1 Diana and hound to the Swedish count" (Noldus 2005: 173). The latter may well have been intended for the great park, where de la Vallé suggested a rather grand layout with a star-shaped system of avenues and a classical temple in the centre.

The correspondence with Peter Trotzig shows that Tott also ordered large quantities of trees and shrubs. To give an idea about what a large scale operation planting and managing 
the gardens was, here are some examples of the imported quantities. In 1661, on one single occasion, 200 lime trees, 300 fig trees, 100 apple trees, 50 plum trees, 500 currant bushes, 500 gooseberry bushes and 1000 rose shrubs intended for Ekolsund was shipped from Amsterdam. Four years later, another large shipment of plants was sent, which included "20 grapevines, half white, half red of the best kind, mulberry and apricot trees". The letters reveal that Tott did supply himself with plants, sculptures and garden books via Trotzig, but also inquired about skilled gardeners who would like to work in Ekolsund (Noldus 2005: 173).

Inventories from 1670 give us a glimpse of the gardens and its plants. For instance, the description of the lesser kitchen garden close to the south building called the "House Garden" or the "Secret Garden", corresponds rather well with the plants sent from Holland. Cherry and quince trees were planted as well as apple and plum trees, both grown from seeds and grafted. Vines were climbing against the garden wall, vegetable beds were surrounded by hedges of red and black currants and centifolia roses, and beds with common barberry and wild strawberries by fruit trees and currant hedges. Planted in chests were non-hardy plants, such as stinking bean trefoils (Anagyris foetida), common bladder senna (Colutea arborescens), silver ragwort (Jacobaea maritima) as well as more hardy species like common laurel (Prunus cerasifera) lavender, carnations and other "flowers" (Riksarkivet, Clas Totts samling E 5796).

Clas Tott would spend a fortune on the transformation of Ekolsund, which ruined him in the end. In 1670 he had to use the estate as a pledge, and no more work could be done. When Tott died childless two years later, the project came to a definite halt (Olausson 1997:172). During a process called the Great Reduction in the 1680s, Ekolsund, like many private landed estates, had to be returned to the Crown. To summarize, despite the enormous efforts that were made during almost 40 years to turn Ekolsund into the most spectacular country house in Sweden, neither Åke Tott, Magnus Gabriel De la Gardie nor Clas Tott would ever enjoy the finished result. Little is known as to how the gardens and parks were used by its seventeenthcentury owners. However, their visions of an estate, on an almost princely level, turned out

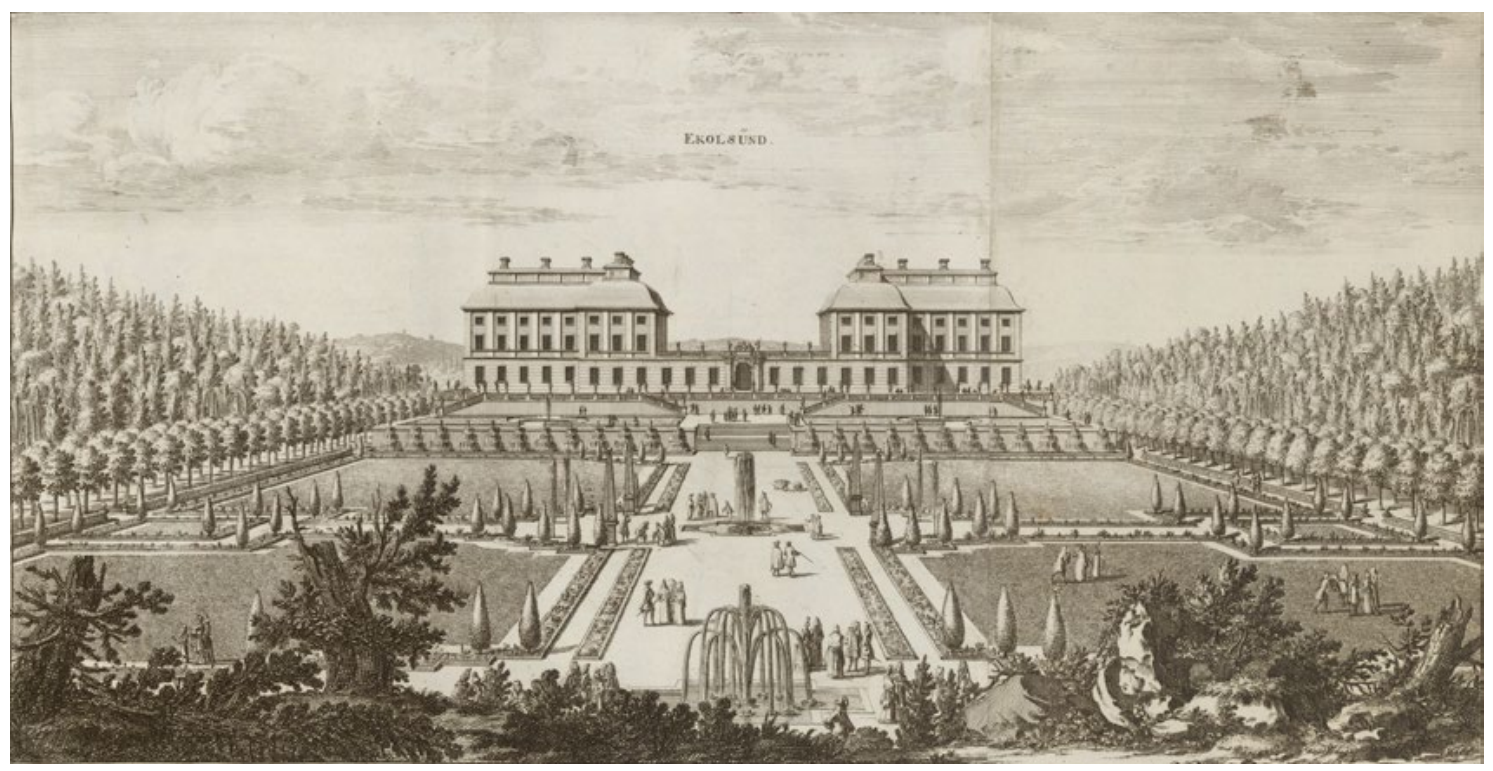

Figure 4. Ekolsund as it appears in Suecia Antiqua et Hodierna, a collection of engravings produced with the aim to present Sweden to the world. The artist Erik Dahlbergh's image is probably representing the owner's vision, rather than the actual garden at the time. The Royal Library, Stockholm. 
to fit the royal country lifestyle well in the eighteenth century (Fig. 4). Ekolsund also became an important source of inspiration for several gardens in Sweden, the royal Drottningholm among them, outside Stockholm.

\section{In royal hands - an escape to the country}

In 1716, after some years in the care of bailiffs, Ekolsund was given to the Prince consort Frederick, newlywed to Princess Ulrika Eleonora. By then, a central element in a baroque garden, a large parterre de broderie designed by the inspector of the royal gardens Johan Hårleman (1662-1707), was finally in place. Hårleman, who had worked at both Chantilly and Versailles during his studies abroad and met Louis XIV's famous garden architect André le Nôtre was well acquainted with the French garden trends (Lundquist 2000: 63; Karling 1971-1973).

A detailed surveyor map from 1725 shows the transformed Ekolsund (Lantmäteristyrelsens arkiv B29-2:1) (Fig. 5). In the very centre, we can see the new parterre in the pleasure garden, which is described as "costly" and "daily maintained", with its box and clipped spruce trees around the quarters, which offered "a nice prospect". The description conveys that many of the waterworks were in need of repair, eleven of the six fountains were functioning and only ten of the twenty-five cascades worked. All the water was supplied by a pond at a higher level [the canal], and transported through buried pipes. The "House Garden" was used for herbal plants and various vegetables, while the main kitchen garden was situated further away. This was also where the head gardener's cottage was found. The map description of the nearby "Pheasant garden" gives insight into the organization of the garden as well as its multipurpose, where utility and pleasure were mixed:

"The pheasant garden is a lovely orchard, where there are all kinds of rare fruit trees, all continuously and well maintained, whatever kind they may be, and which are without distinction are planted in quarters, surrounded by barberry bedges. There are also fruit trees along the paths and the beds with root crops, which contributes greatly to the utility and appealing appearance. The most delicious fruits are yearly distributed to His Majesty the King and the Royal Court according to their needs, while the rest is sold." (Lantmäteristyrelsens arkiv B29-2:1).

The map explanation also informs us that in the adjacent kitchen garden a variety of root crops were grown every year, which were primarily consumed at the estate, however, the surplus was sold in the open market. The text continues by characterizing the nearby area called Parnassus as an "overly pleasant mount, in the wild woods, which due to its higher situation than the garden, offers a beautiful view through all the surrounding avenues. There are also a lot of pleasant rooms and paths in the wild woods..." (Lantmäteristyrelsens arkiv B29-2:1).

In addition, there was a large nursery, which appeared to have mainly been used for the propagation of fruit trees, but according to the 1725 map description, it had been badly hit by the severe winter of 1709. Extensive fenced-in hunting grounds are also indicated, but according to the description, the Great Park was used as meadowland and contained no more game and the Little Park was used for grazing. Around 1740, King Frederik I commissioned the country's most well-educated and prominent building and garden architect, Carl Hårleman (1700-1752), son of court gardener Johan Hårleman, to make a new plan for Ekolsund. The problem with the missing middle section of the house had to 


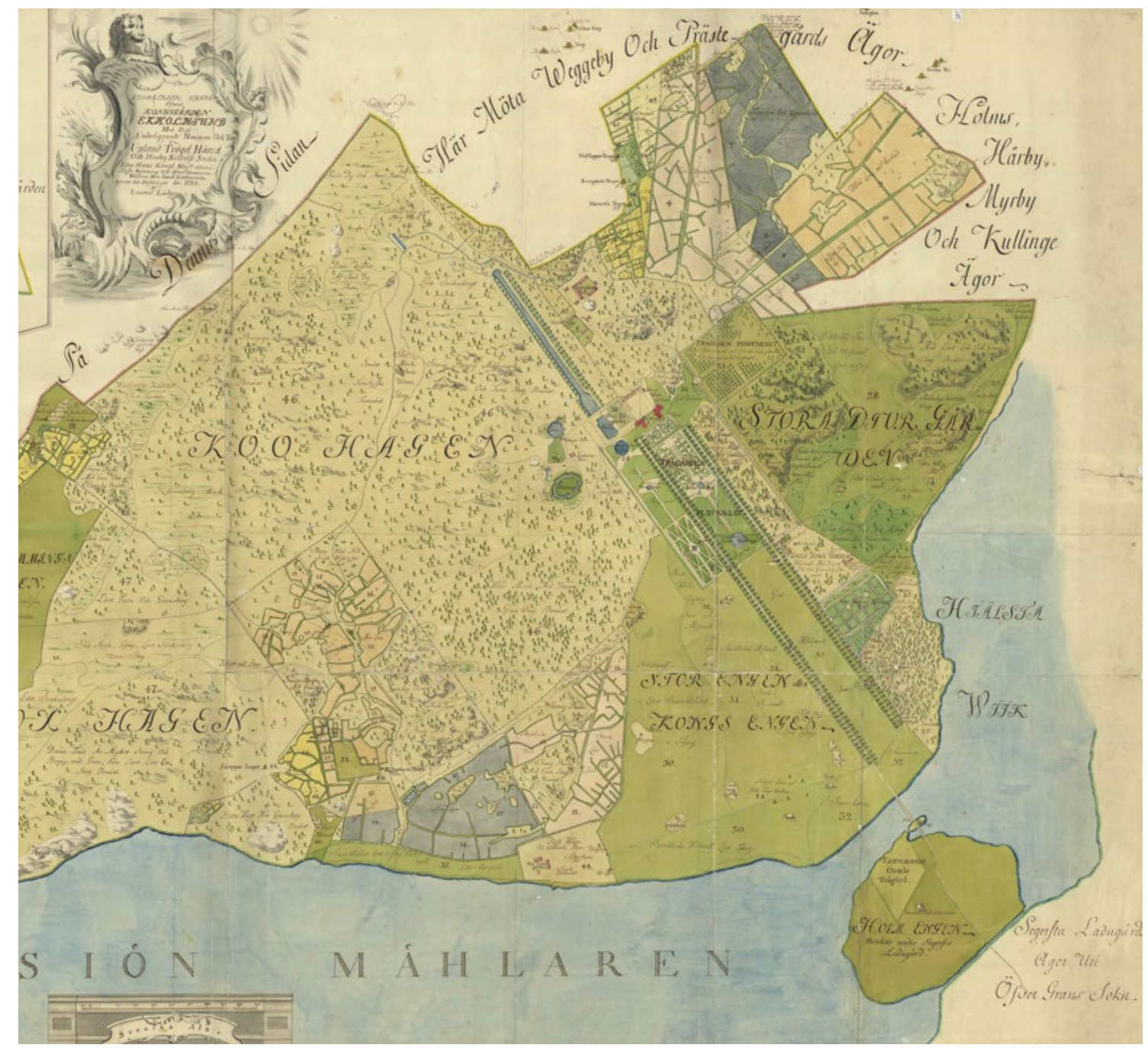

Figure 5. Surveyor map from 1725 showing the designed landscape at Ekolsund. In the centre the gardens with parterres, bosquets, waterworks and grand avenues. On the right the Great and Little Park (Stora Djurgärden and Lilla Djurgarden), the kitchen gardens, the Pheasant garden and the Parnasse. The medieval manor was situated on the small island. Modified (detail). LSA: B29-2:1, Lantmäteriet.

be addressed, and the garden completed. The plan shows that Hårleman's intention was to keep his father's now slightly old-fashion parterre de broderie, while the rest of the pleasure garden would be updated with a more simplified design. Some of the dilapidated waterworks were to be replaced by carefully shaped grass elements, such as parterres, round beds and slopes and the woodland area on the north side finally turned into bosquets underlining the symmetry and the central axis (Olausson 2000:131-133). Hårleman also made a couple of suggestions for a corps de logis, which were never built. However, a lower exedra shaped stable block was constructed in the forecourt, which connected the two side buildings, and only minor works were done in the gardens.

Frederick I would particularly use Ekolsund to pursue hunting, a favourite pastime, but would also engage in other lines of royal entertainment, including parties and feasts of various kinds. However, in the mid-1740s, the estate was given to the future Gustavus III (1746-1792), who would embrace it as a country retreat and spend a lot of time there as crown prince and monarch (Fig. 6). Ekolsund represented a more relaxed lifestyle with family 


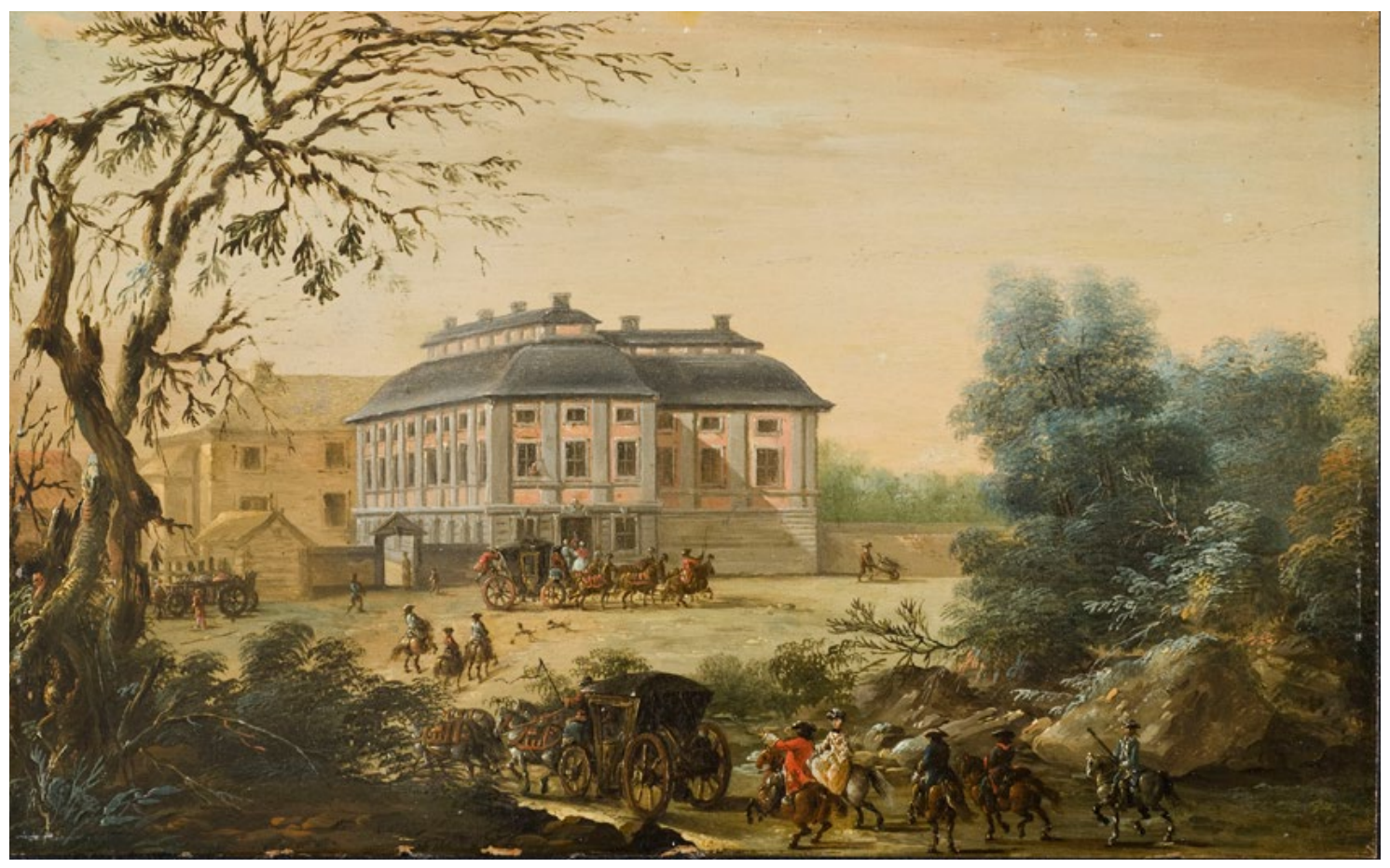

Figure 6. This lively scene is Johan Philip Korn's (1727-1796) version of royal life at Ekolsund during the era of Gustavus III. Note the gardener with his wheel barrel. Photograph by Erik Cornelius/Nationalmuseum Attribution-ShareAlike 4.0 International (CC BY-SA 4.0) https://digitaltmuseum.se/021046499750/ ekolsunds-slott.

and selected circle of friends, a break from the formality of the court life in Stockholm, where a more pleasant, free, merry and cultivated conversation and approach to social life developed (Hennings 1935: 142-145; Hennings 1967: 28, 157). In 1772, Gustavus even introduced a special garment called the Ekolsund attire, only to be worn by a limited group of loyal courtiers and friends during visits. Enjoying the gardens and the landscape was of an important part of country life and would include dining al fresco, promenades, excursions and hunts. Ekolsund would also be used for birthdays and other lavish celebrations, visits of diplomats and other foreign guests, and occasional special divertissements such as the three day long tournaments - one of the King's passions - in the summer of 1776 (Fischerström 1951: 21-22, 102-104; Hedvig Elisabet Charlotta 1908: 17-18, 52-54; Hennings 1967: 119120; Olausson 1993: 401-402, 545). This is also where he withdrew after his coup d'état in August 1772 and inscribed the words " 12 September 1772 returned here from the revolution. Gustaf" in one of the windows in his study at Ekolsund.

Gustavus modernised and redecorated the main buildings and, not long after his first tour abroad in 1770-71, he also devoted a lot of energy to the gardens and parks. In Paris, Gustavus had met with the Swedish courtier and amateur architect Adolf Fredrik Barnekow (1744-1787) who then continued for a shorter sojourn to London where he was taken by the English approach to garden design. On his return, Barnekow worked with Gustavus III on various projects during the 1770s to redesign Ekolsund, which are probably the first attempts at creating a landscape garden in Sweden. Winding walks would be introduced, together with meandering canals and various garden buildings. In some plans, the pleasure garden was subject to change, while in others, areas like the Great Park and the large King's meadow were to be included and turned into landscape gardens, and as such, integrated 
with the existing gardens. Interestingly, even if the plans had been completely implemented, they would still not change the main structures of the existing landscape, but all submit to the seventeenth-century layout. Despite the quest for a new approach, the principles of the baroque landscape would not really be challenged (Olausson 1993: 400-408).

Only a fraction of the intentions was realized. In the pleasure garden, the old embroidery parterre was replaced by a simplified grass parterre and the cascades by ramps. A complicated network of meandering walkways was laid out on the north side of the parterre, while the bosquets on the south side were kept (Olausson 1993: 406-407). The Parnassus was extended and replanted (Olausson 1993: 397). However, once Gustavus III got access to the Drottningholm Palace outside Stockholm in 1777, he lost interest in creating a new garden scheme at Ekolsund. Only a few years later the Swedish garden architect Fredrik Magnus Piper would be back from England and would create garden plans for both Drottningholm and Haga (Olausson 1993: 421-425, 460-474).

\section{The era of capitalists}

In order to finance new building and landscape projects, Gustavus III sold Ekolsund in 1785. The buyer was the wealthy unmarried Scottish nobleman George Seton (1696-1786), who had successfully established himself as a wholesaler and banker in Sweden (Lazarus 1905: 237-238; Seton 1941: 582-586). In connection with the purchase, George Seton received the patent of nobility in Sweden - still a requirement for owning a manor. The reason for the old and childless George Seton to buy a property of this scale was probably a means to invest his fortune. It perhaps also mirrored a desire to manifest his achievements and establish his family in the new country. Just a few months later, his adopted nephew Alexander Baron Seton inherited the estate, which would stay with the Setons for well over a century, passing down the generations until 1912 when it was sold after the death of Patrick Seton.

Despite the family's long possession, surprisingly little is known about this period. The impression is that the focus was on agricultural production, which included a substantial dairy production with Ayrshire cattle (Tham 1850: 125). Some of the Setons appear to have spent more time in Ekolsund, while others did not stay there at all. The fact that the family seat Preston was kept in Scotland probably had bearing on this. The mid-century topographical account of Wilhelm Tham briefly mentions an imposing manor surrounded by substantial gardens and parks, however, through the diary of Edla Ulrich (1816-1897), partly written in French, there is a more personal and detailed account. The estate was at that time leased by Carl Gustaf Adlercreutz (1799-1883), who was married to Margaret Seton (1808-1870), the sister of the then owner Alexander Seton (1806-1884) (Söderberg 1967: 147). Edla stayed with her friends at Ekolsund in the summer of 1851 and her diary shows that the property was not all about economy and utility, but used for recreational and representative purposes as well. On one occasion Edla writes that, while the visiting gentlemen were inquiring about agricultural matters, the ladies accompanied by a young lieutenant took a walk to the so-called Parnassus. Edla describes it as "a charming park," where there once had been sculptures of Apollo and the nine muses. She appreciates the closeness to the lake and wild swans swimming in the water which contributes to la poésie $d u$ paysage, the poetry of the landscape. On that note, she continues: "It was in vain, however, that we tried to excite Lieutenant Kraemer, who is a little poet, to improvise something in this place, which, if only for its name, should open up all poetic veins." (Ulrich \& Ulrich 


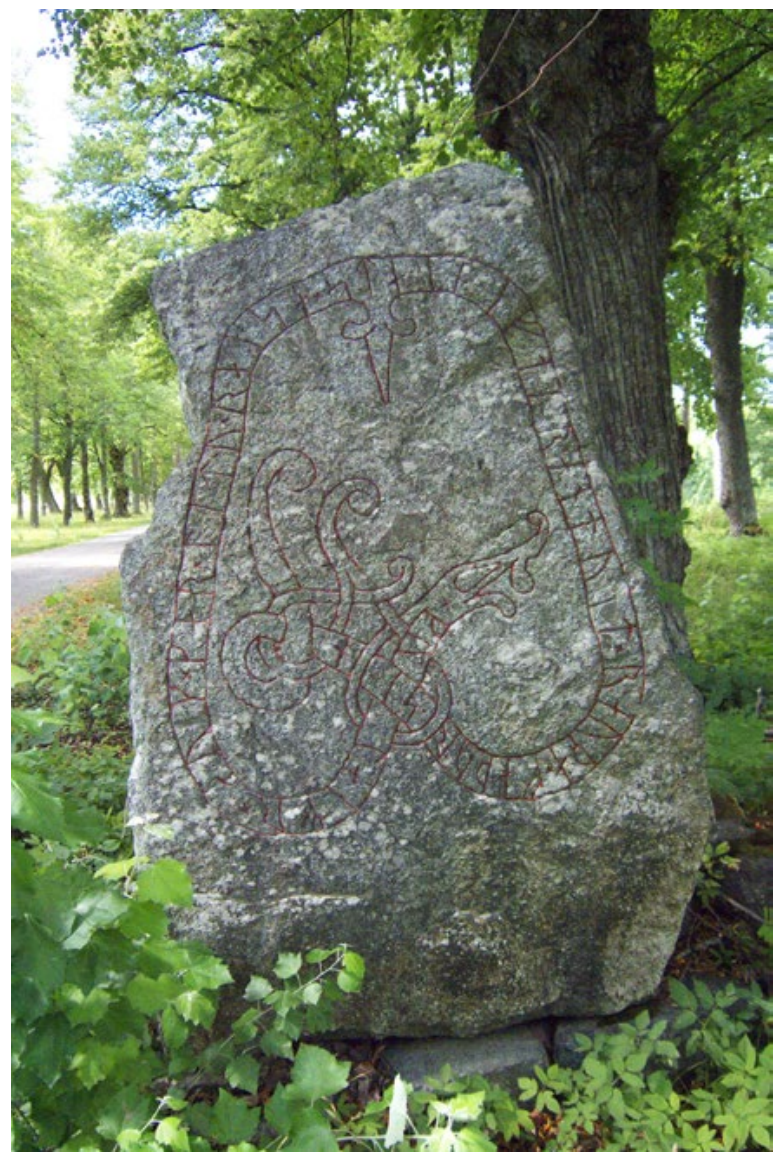

Figure 7 . One of the runic stones greeting the visitor by the main entrance leading into the south avenue. The stones were moved from their original locations to the garden inEkolsund in the 1820s. The inscription says "Gulleif and Kar raised the stone after Andvett rode, their father”. CC0 1.0 Universal Public Domain Dedication.
2016: 274).

Edla's accounts convey that the women went for daily walks together in the garden, the grand avenue as well as the wider landscape, sometimes just chatting away, other times discussing literature in the English language such as Charlotte Brontë's novel Jane Eyre or works by Shakespeare. Perhaps after an encounter with the runic stones in the garden (Fig. 7), Edla borrowed a book on Swedish runic stones from the library, and interestingly, John Locke's An essay on buman understanding, "of which I would like to know, as much as time permits, while I am here" (Ulrich \& Ulrich 2016: 275). Locke's ideas on the human mind and how we gain knowledge by experiencing the world through our senses was of great importance to the development of the landscape garden, and the relation to landscapes generally from the eighteenth century onwards. Edla and her friend Ebba Adlercreutz went by boat on the canal one evening, "so that we could enjoy the beautiful shores of the Lake Mälaren, enhanced by the effect of the moon that had just appeared. Inspired by the beauty of the evening, we performed a kind of duets, me singing, and Ebba whistling, which she does delightfully." (Ulrich \& Ulrich 2016: 275). It turns out that lieutenant Kraemer had been poetically inspired by the landscape after all, not at the Parnassus, but by the beautiful view of the sunset from the Husby (Sjutolft) church nearby (Ulrich \& Ulrich 2016: 276).

After a couple of weeks, Edla Ulrich's stay at Ekolsund had come to an end. On the day of departure, she got up early in the morning "to have the time to enjoy some of nature, after finishing my packing. I am now sitting at the open window of my room, imbibing the fresh air of the morning and, trying, so to speak, to instill in my soul the impression of the charming sight which extends before my eyes, and which I may be looking at for the last time" (Ulrich \& Ulrich 2016: 277). Carl Stefan Bennet's (1800-1878) undated painting, Gentry at the Ekolsund Manor seems to underline the impression of Edla Ulrich's diary about the way the designed landscape formed as part of daily life (Fig. 8). Despite the straight avenues and grand open view, the garden is informal, rather than formal, and well in tune with landscape ideals of the time. The atmosphere is relaxed, everybody in the little group is comfortably dressed and seems to be enjoying the informality of country life. During the Seton era, fountains, bosquets, steps and several of the ponds disappeared. The terraces were made into slopes and the parterres turned into a large open surface, eventually planted with fruit 
trees (Hernmarck 1964: 527-528) (Fig. 9). Some of the measures taken were probably due to changing ideals. The formal French garden was completely out of date, but they were no doubt also a testimony to a general lack of interest and economic resources.

From the 1870s onwards, during the last Seton generation, hunting appears to have been a favourite pastime at Ekolsund. The owner Patrick Seton (1849-1911), who was appointed Hovjägmästare (Master of the Chase) at the Swedish court, arranged, for instance, a grand royal swan hunt in 1885 for King Oscar II and his guest the Prince of Wales, later Edward VII (Söderberg 1967: 152). A few years later, 1892, a large kennel was built, designed by Ragnar Östberg, the future architect of the City Hall in Stockholm. Despite the strong ties with Scotland, it seems that Ekolsund was a place of great emotional and symbolic importance to the Seton family. Perhaps a testimony of that is the fact that among the names they chose for their coffee and tea plantations in the colonial Ceylon were not only Preston, Augusta and Bellair, but Segersta and Ekolsund. The latter is still an estate in present-day Sri Lanka (Mogren 2009: 185).

Once the estate in Sweden had been sold to a consortium in the early twentieth century, the land was divided into several estates. In 1917, Ekolsund was bought by the wealthy industrialist Carl Kempe. The home farm and some of the land came with the manor in 1947, however, the agricultural operation was sold, leaving only a small core area surrounding the houses and the immediate gardens (Länsstyrelsen Uppsala län 2016; Söderberg 1967: 146-147).

The buildings, as well as the surrounding landscape, were in a poor state when Kempe acquired Ekolsund. In 1851, when Edla Ulrich visited what she called the vieux chatteau, the south building, Gustavus III's former apartments were already uninhibited and dilapidated, though in Edla's mind they still reflected the great events that had taken place in the vast rooms. Like many others, she wrote her name on the wall in the same room as the revolution inscription of Gustavus (Ulrich \& Ulrich 2016: 273). The building was even used as a granary for a period of time by the Setons, who inhabited the north building (Söderberg 1967:152). Kempe, however, had his mind set on restoring it back to its former glory. A comprehensive restoration of the south building was carried out in the 1920s, and the rooms were furnished over the years with collected furniture and other objects, many of which from the seventeenth and eighteenth century (Söderberg 1967: 155-164). Carl Kempe belonged to a dynasty of forestry industrialists. With great passion, he created an arboretum in order to scientifically test the suitability of various species as forest trees primarily in the area south of the garden (Fig. $10 \mathrm{a} \& \mathrm{~b}$ ). The arboretum was built around a core of coniferous trees planted during the Seton era (Nitzelius 1962: 6-7). Kempe maintained the large pleasure garden and many of the remaining structures such as avenues, ponds, canals and paths were kept and some were repaired. For a long time, the intensive upkeep seems to have been reserved for the area around the two main buildings, where there would be flowerbeds, mowed lawns, ornamental trees as well as a kitchen garden with greenhouses and an orchard (Hernmarck 1964: 525-529; Söderberg 1967: 152). In a description from the 1960s, the cultural historian Bengt Söderberg writes: "We drive slowly through the left avenue. To the right, a whitish undulating cornfield on the vast rectangle of the former fountain parterre, and on the long slope beneath the palace terrace, where cascades gushed down the water stairs 200 years ago, potatoes are in blossom; on the grass there is a battery of four cannons, which probably have saluted many distinguished palace guests." (Söderberg 1967: 152). 


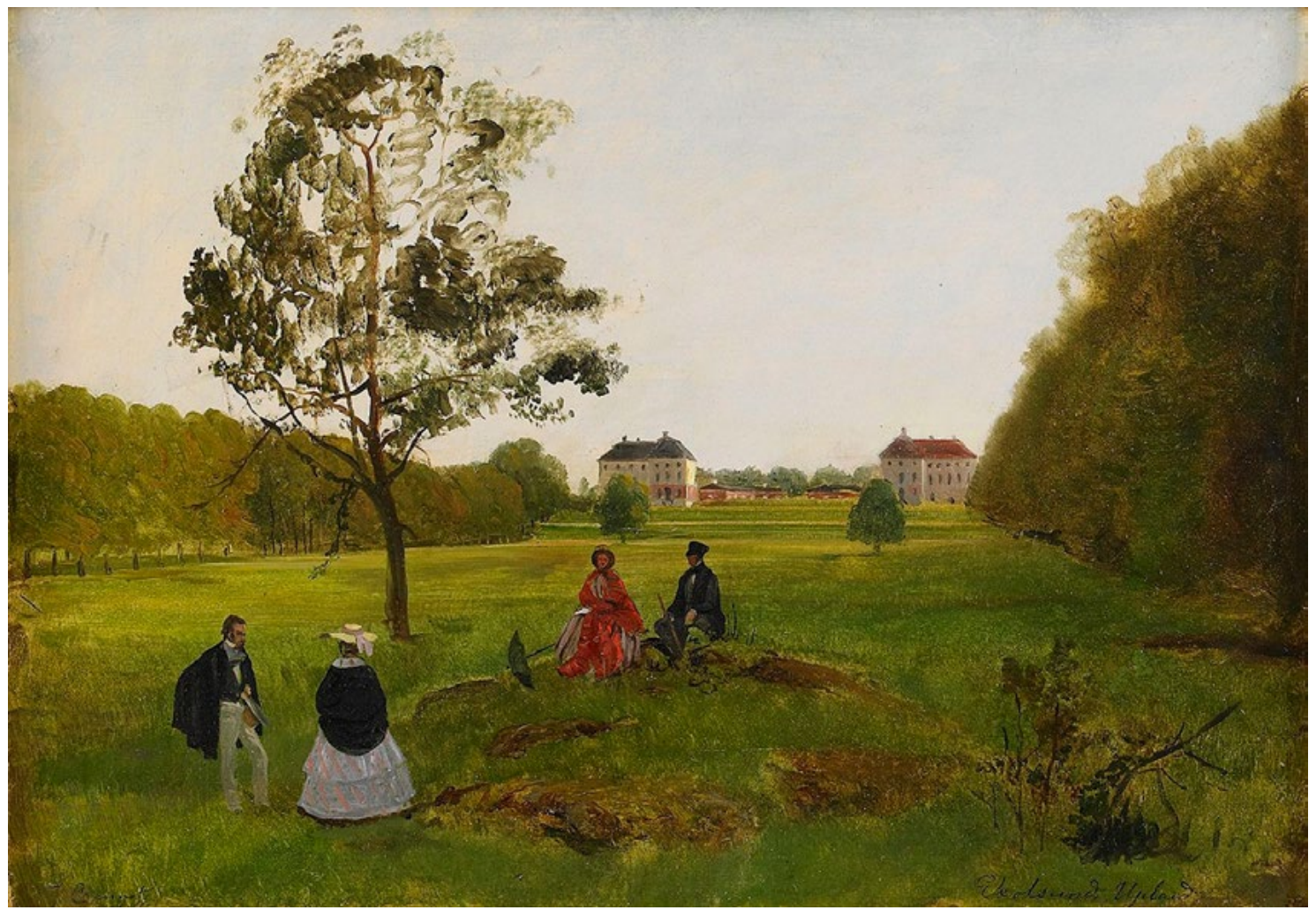

Figure 8. Carl Stefan Bennet's painting "Gentry at the Ekolsund Manor" conveys a sense of relaxed atmosphere and the informality of nineteenth-century country life. (Photograph by Stockholms auktionsverk) Public domain.

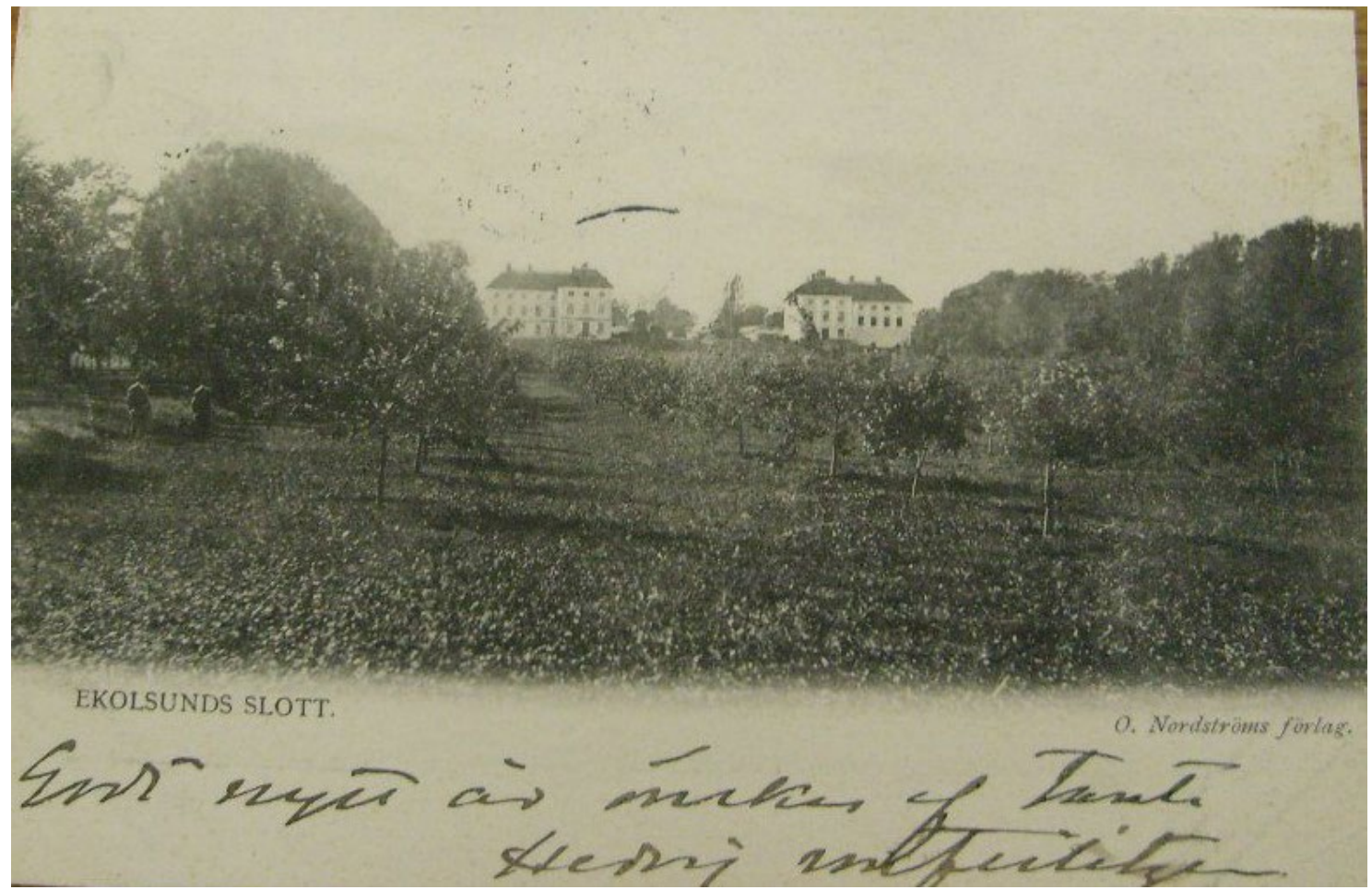

Figure 9. Christmas greetings 1903 on a postcard featuring the former parterres with rows of fruit trees in the garden at Ekolsund. 
Since medieval times, the important road between Stockholm and the Bergslagen region has passed through Ekolsund. Iron and copper, produced in Bergslagen and shipped from the capital via the road, formed the foundation of the Swedish economy for a long time (Magnusson 2008:61-65). During the first part of the twentieth century, the road was widened and modernized. The road section around Ekolsund was rerouted without much regard to the historical structures in the landscape. The new road intersected the Great Park, the pleasure garden and the fields in front of the manor, in order to finally connect to the old road through the south avenue. The north avenue that had been an equally important structure in the baroque landscape, tying together the pleasure garden, the parks, the kitchen garden and the Parnassus, was now removed from the wider landscape, making the coherence less obvious. During the Seton era, a new connecting road had been built with a bridge leading over the garden canal, which was replaced by a modern version in the twentieth century (Lantmäteristyrelsens arkiv B29-2:2, Rikets allmänna kartverksarkiv, Husby-Sjutolft J133-11h3h53).

In 1969, two years after Carl Kempe's death, Ekolsund was listed as a Historical Building due to its historical significance. The regulations stated that the interior and exterior of the buildings should be satisfactorily maintained and were not to be altered without the consent from the Swedish National Heritage Board. The surrounding garden area (called the park area in the document) was not to be built on or in any other way be significantly altered and should be maintained in a dignified condition (Riksantikvarieämbetet 16 Jan 1969). The indicated area, however, does not comply with the outline of the historic landscape but relates to later structures such as the road system and more fragmented land ownership. The
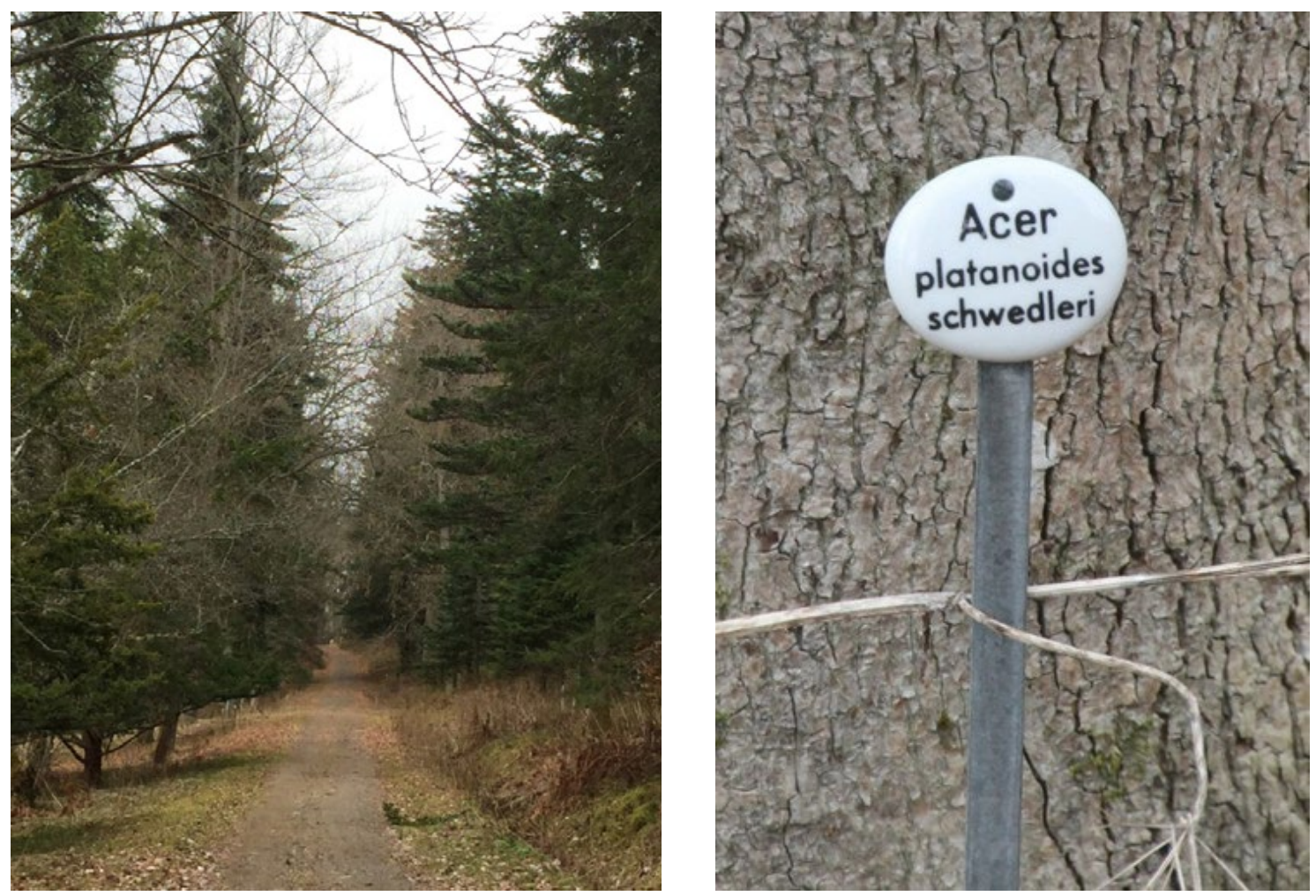

Figure $10 \mathrm{a} \& \mathrm{~b}$. In the twentieth century, Carl Kempe created an extensive arboretum primarily to test the suitability of various species as forest trees. Many trees were provided with specially made porcelain labels. Photograph by Åsa Ahrland. 
consequence of which is that only a part of the garden canal is included in the protected area while the south avenue along the public road, the Parnassus and the parks, are excluded. The extent of the protected area has not changed, yet, a greater awareness of the significance of the landscape context can be detected today with the responsible authorities, the County Administrative Board in Uppsala. Regarding the qualities of the Historical Building, they state that: "Ekolsund palace constitutes a coherent entirety with distinct traces of gardens, avenues and parks that extend far beyond the actual palace area." (Länsstyrelsen Uppsala län 2016).

The area around the nearby Lake Hjälstaviken was a designated Nature Reserve in 1982, particularly due to the rich birdlife associated with the wetlands. The regulations also include conserving biodiversity in general, safeguarding the cultural heritage and aesthetic values, and making the landscape accessible for recreation. The large 800 -hectare reserve incorporates, in part, the core of the historic manor landscape of Ekolsund, the former Great and Little Park, the nursery, the area of the former kitchen garden, a little of the garden, the Parnassus and remains of the North Avenue (Länsstyrelsen Uppsala län 2016).

\section{The era of events - opening up to the public}

In 2001, the Kempe family sold Ekolsund manor to the present owner, Raija Ohlin, who also acquired the old Ekolsund inn by the road. Since then, the south wing, which is the home of the owner family, and the inn have been restored. The pleasure garden is managed with the aim to retain and define the old structures, prohibit further decay and conserve the biodiversity, which includes keeping the former parterre area open and the canal and ponds cleared, removing brushwood and managing and planting trees. A management plan for the approximately 1000 avenue trees in and around the garden, the majority of which are lime trees, has been developed (Fig. 11). Inventories regarding biodiversity show that the old avenue trees are habitat to more than 30 red-listed species (Bengtsson \& Harris 2013: 7-8). During the last two decades, there has also been a renewed interest to document and develop the arboretum. The area is dominated by groups of various coniferous and deciduous trees from Europe, North America and East Asia, but also contains individual exotics, such as Amur cork tree (Phellodendron amurense), Caucasian wingnut (Pterocarya fraxinifolia), ginkgo (Ginkgo biloba), tulip tree (Liriodendron tulipifera), chestnut (Castanea sativa), katsura (Cercidiphyllum japonicum) and several species of walnut (Juglans regia, J. cinerea, J. nigra, and J. mandshurica) (Ekolsunds slott 2018). The work includes thinning, clearing and planting. In the former Great Park, a plantation of spruce from the latter half of the twentieth century has been removed with the aim to create a landscape with leafy and open pastures as well as groves and woodland (Länsstyrelsen Uppsala län 2016: 47).

After the reintroduction of red deer and fallow deer, the fenced-in area is now managed as a park, although, due to its Nature Reserve status, with regard to biodiversity (Fig. 12).

The aim is to open up the manor and its surroundings by offering a wide range of events built around the cultural and natural values of the site: guided tours of the house, park, tree and bird-watching walks, trap-shooting, hotel overnights, conferences, weddings and other celebrations. In addition, the site is frequently used for film and television productions. The pleasure garden, the arboretum and the Nature Reserve, with the exception of the fenced-in park, are open to the public (Ekolsunds slott 2019). Hence, more or less the whole area is today accessible to visitors in order to explore the history of the landscape and the biodiversity in which it has resulted. 


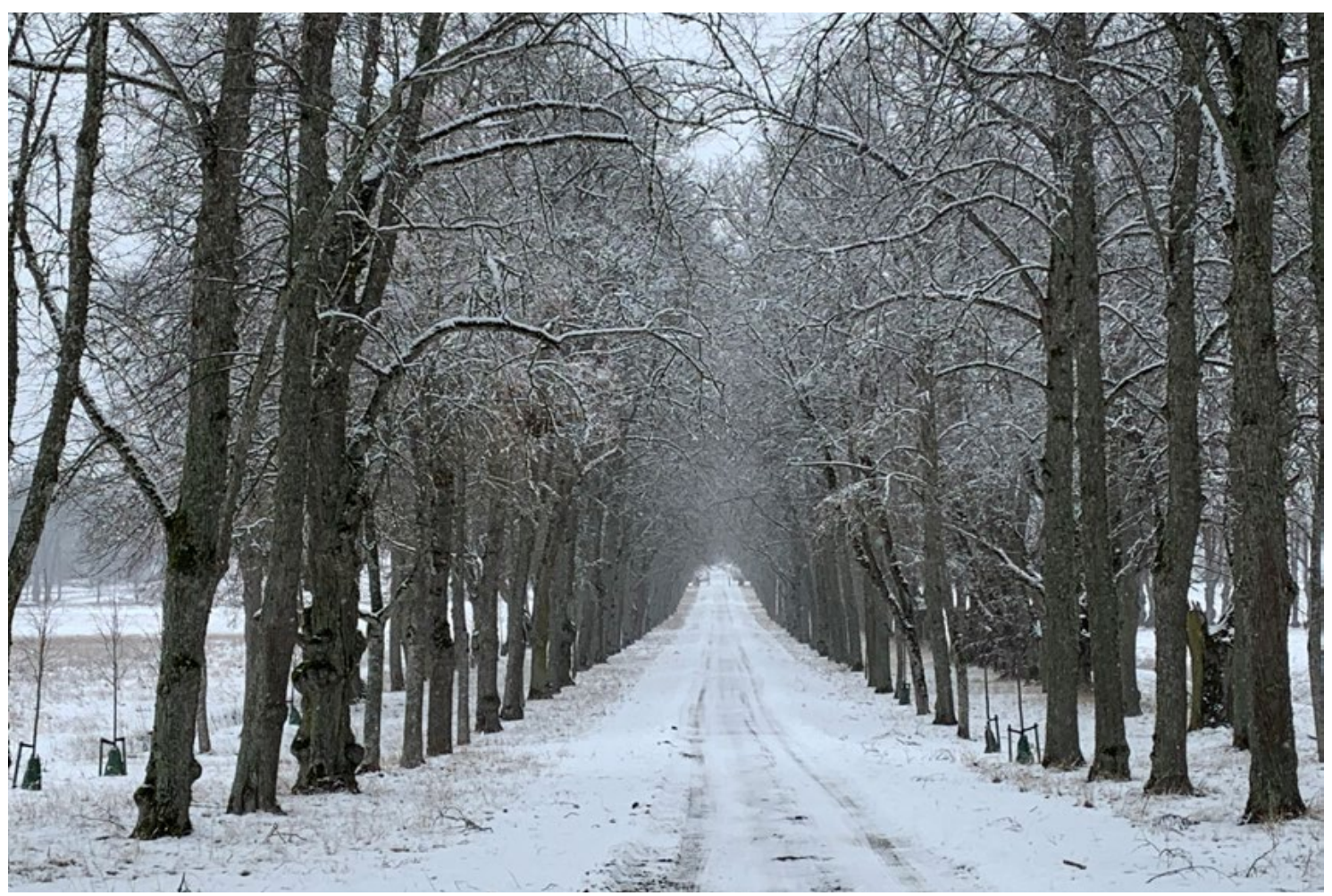

Figure 11. The south double avenue in Ekolsund during winter. The old lime trees constitute a cultural heritage and at the same time a habitat to endangered species. Note the new trees with their watering bags. Photograph by Åsa Ahrland.

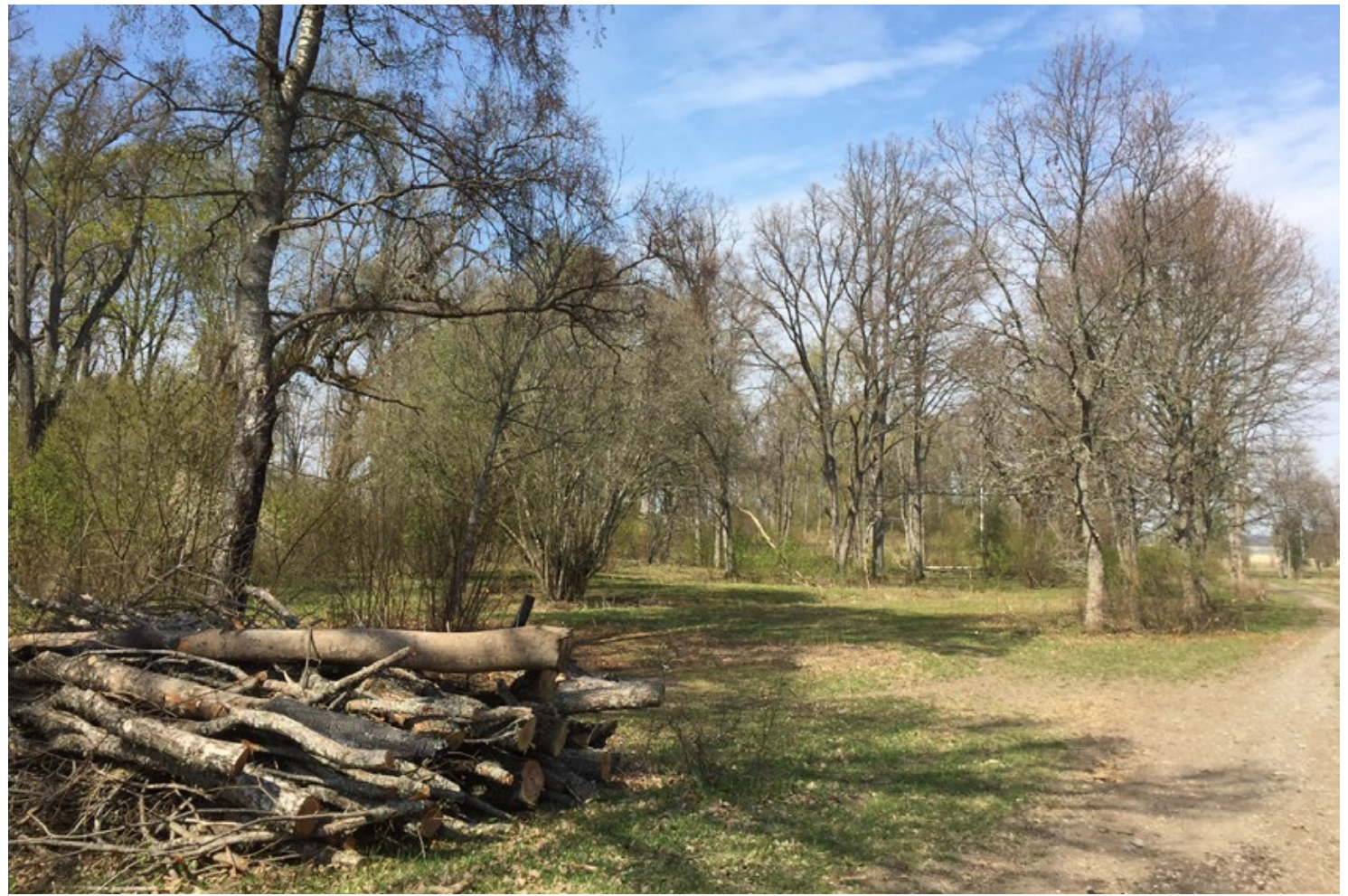

Figure 12. In the former Great Park, the twentieth-century spruce plantation has been replaced by a fenced in area with open pastures, groves and woodland as well as reintroduced deer. The park is managed with regard to biodiversity. Photograph by Åsa Ahrland. 


\section{Conclusions}

It is evident that the designed landscape at Ekolsund today is characterized by a multitude of layers, reflecting visions past and present of the manor and its setting, but also its varying political and socio-economic contexts. Ekolsund was created as a work of art, a display of cultivation and wealth to be enjoyed by aristocratic owners and their guests. The financing was based on income from the wars and the agricultural production of the estates of the field marshals, Ake and Claes Tott. The enterprise is a testimony of an emerging wealthy élite and its need to manifest itself according to the latest fashion during the Era of the Great Powers. In the eighteenth century, Ekolsund was turned into a royal retreat, where country life was enjoyed with less formality and within a selected circle. While the estate still constituted an important income, the economy was mostly linked to politics and the state's finances. The fact that a successful wholesaler, very much a self-made businessman, despite the pedigree, could buy a major royal manor in the 1780 s, was probably an early sign of political change. A feudal structure such as the Swedish nobility's exclusive right to own manors would cease in 1810, which opened up the opportunity to wealthy businessmen and early industrialists to acquire a country estate (Ulväng 2017: 50-51). Although the production at Ekolsund seems to have been the focus, as well as the financial foundation during the Seton era, paintings and diaries show that the owners and their guests took great pleasure in experiencing the slightly overgrown and dilapidated gardens and the surrounding landscape.

The changes brought about by modern society are obvious when it comes to Carl Kempe and the way he financed Ekolsund. The Kempe family had built up a fortune within forestry in the north of Sweden during the nineteenth century. Carl Kempe was a highly successful industrialist who did not need the income from Ekolsund, but used the earnings from industrial enterprises elsewhere. To him, Ekolsund was a magnificent former royal summer palace that he took on to restore in order to create an exclusive home for himself and his family. Ekolsund was the appropriate setting for his extraordinary collections of Chinese ceramics and other works of art, and equally suitable for the collection of interesting trees in the arboretum. Kempe and his wife are even buried in the Island of Bliss, a remote and never finished part of the seventeenth-century garden.

As a result of the development during the twentieth century, the agricultural potential at Ekolsund, the traditional backbone of a manor, is no longer available. Today nature conservation has become a new and interesting alternative to manage the land. Tourism and hospitality businesses also form a part of the financial foundation. To conclude, Ekolsund has kept its attraction through the centuries, and a key factor has been the relationship to and experience of the landscape and its history. From being private and secluded, only to be experienced by a selected few, it is now open to the general public to enjoy.

Though the original plans never were completed, and there have been later alterations and a need to simplify, Ekolsund is still one of the best kept seventeenth-century gardens and landscapes in Sweden. The overall scheme is more or less intact. Many structures have survived, while others are hardly visible or have completely disappeared. The main avenues still underline the central axis of the gardens and connect the buildings to the landscape. The remnants of the waterworks, such as fountains, cascades, ponds, and the 570-metre long canal, remain important features in the gardens while the layout of the large embroidery and grass parterres in the centre are only suggested by a mowing regime. There are not bosquets, but an extensive arboretum containing around 140 species of trees and shrubs. 
Little remains of the kitchen gardens and nurseries. Many of the old trees, in combination with a long history of management of the gardens and grounds (sometimes intensive and sometimes extensive), have provided rich flora and fauna, including great numbers of redlisted species of insects, lichens and fungi.

The landscape at Ekolsund also holds other less obvious dimensions, such as people's view of nature and other ideas, mirrored in its design and usage by different people over time and periods of decay and dilapidation as well as of renewal and restoration. It constitutes cultural heritage, but it is also a place of biodiversity and other values, which is mirrored in the various legal instruments that have been used to protect and safeguard the landscape. Due to its cultural significance, the manor is protected as a historical monument, which also includes the gardens. The former deer parks now form part of a nature reserve, particularly well-known for its rich and interesting birdlife.

So, how shall the landscape at Ekolsund be approached? One could argue that such an important and unique seventeenth-century landscape, if possible, deserves a full-scale restoration. Many structures remain, the conditions for archaeological excavations and surveys are favourable, and there is a fair amount of seventeenth-century documentation, particularly plans and maps. Many of the requirements for conducting a well-grounded and interesting reconstruction are met. However, the result would only represent one layer in the history of Ekolsund, not the various visions and actions of different agents over time that together have shaped the place. It should also be taken into account that the seventeenthcentury scheme was never completed, and the plans were constantly renewed and changed. Therefore, a holistic approach is suggested, focusing on maintaining and visualizing different historical narratives and layers of the landscape. It also includes to conserve and develop a landscape, where cultural and natural values complement rather than oppose each other. The complexity of a multilayered landscape such as Ekolsund is particularly suitable for inventive conservation strategies, which require a continued collaboration between different research disciplines as well as the cultural heritage and nature conservation sectors.

\section{Acknowledgements}

This article is a result of work conducted within a project on the cultural history of gardens, parks and designed landscapes in Sweden financed by The Royal Swedish Academy of Letters, History and Antiquities, the foundations Stiftelsen Lagersberg and C. F Lundströms Stiftelse, and The Royal Swedish Academy of Agriculture and Forestry.

\section{References}

Bengtsson, V. \& R. Harris, 2013. Trädvårdsplan för Ekolsunds slottspark i Uppsala län, Pro natura, Urban Forestry (Bury St Edmunds) Arborists and Landscapers. Accessed 31 Oct 2018. http:// www.pro-natura.net/publikat-filer/Rapport $\% 20$ Ekolsund_130703_slutversion_med $\% 20$ kartor.pdf.

BJÖRKLund, A., 2014. Det medeltida Sverige Bd 1 Uppland. 10 Tiundaland: Håbo härad, Sigtuna stad. Stockholm: Riksarkivet.

DAHL, P., 1995. Svensk ingenjörskonst under stormaktstiden: Olof Rudbecks tekniska undervisning och praktiska verksambet. Diss. Uppsala: Univ.

EKOLSUndS SLOTT 2018. Accessed 4 Nov 2018. http://www5.ekolsundsslott.se/. EkOLSunds Slott 2019. Accessed 22 Nov 2019. https://www.ekolsundsslott.se/. 
Ellehag, C., 2003. Jean de la Vallée: kunglig arkitekt. Lund: Signum.

FISCHERSTRÖM, J., 1951. En gustaviansk dagbok: Johan Fischerströms anteckningar för året 1773. Stockholm: Lagerström.

Hedvig Elisabet Charlotta, 1908. Hedvig Elisabeth Charlottas dagbok 1, 1775-1782. [2 Ed.] Stockholm: Norstedt.

Hennings, B., 1935. Gustav III som kenprins. Diss. Stockholm: Högskola.

Hennings, B., 1967. Gustav III, [New Ed.], Stockholm: PAN/Norstedt.

Hernmarck, C., 1964. Ekolsunds trädgård, in: S. Ulfisarre, B. Lyberg \& B. Gyllensvärd (eds), Festskrift tillägnad Carl Kempe 80 arr: 1884-1964. Stockholm: Almqvist \& Wiksell, 517-538. KARLING, S., 1931. Trädgårdskonstens historia i Sverige: intill Le Nôtrestilens genombrott. Stockholm: Bonniers.

KARLING, S., 1971-73. Johan Hårleman, in: Svensket biografiskt lexikon (SBL) Bd 19, 592-596. Länsstyrelsen Uppsala län , 25 Nov 2016. Accessed 6 Nov 2018. file://C:/Users/asaahr/ Downloads $/ \mathrm{Hj} \% \mathrm{C} 3 \%$ A4lstaviken $\% 20$ beslut $\% 20161125 \% 20$ och $\% 20$ regeringsbeslut $\% 20$ 181018\%20(2).pdf.

LANTMÄTERISTYRELSENS ARKIV: Husby-Sjutolft socken Ekholmssund eller Ekolsund 1, Ägomätning 1725, B29-2:1. Accessed 11 Oct 2018. https://historiskakartor.lantmateriet. $\mathrm{se} /$ historiskakartor $/$ show.html showmap $=$ true\&archive $=$ LMS\&nbOfImages $=11$ \&sd_ base $=$ lms2\&sd_ktun $=4 \mathrm{c} 4 \mathrm{~d} 535 \mathrm{f} 4232392 \mathrm{~d} 323 \mathrm{a} 31$.

LANTMÄTERISTYRELSENS ARKIV: Husby-Sjutolft socken Ekholmssund eller Ekolsund 1, Laga skifte 1912, B29-2:2. Accessed 8 Nov 2018. https://historiskakartor.lantmateriet. se $/$ historiskakartor $/$ show.html show map $=$ true \&archive $=$ LMS\&nbOfImages $=42 \& s d_{-}$ base $=$ lms2\&sd_ktun $=4 \mathrm{c} 4 \mathrm{~d} 535 \mathrm{f} 4232392 \mathrm{~d} 323 \mathrm{a} 32 \& \mathrm{p}=3$

RiKETS ALLMÄNNA KARTVERKS ARKIV: Ekonomiska kartan 1951, Husby- Sjutolft J133 11H3h53 Accessed 8 Nov 2018.

https:// historiskakartor.lantmateriet.se/historiskakartor/show. html? showmap=true $\&$ archive $=$ RAK\&archive $=$ RAK\&sd_base $=$ rak2\&sd_ ktun $=52414 \mathrm{~b} 5 \mathrm{f} 4 \mathrm{a} 3133332 \mathrm{~d} 31314833683533$.

LAZARus [PSEUd. C. F. LiNDAHL], 1905. Svenska millionärer: minnen och anteckningar. Vol. 10. Stockholm.

Lundquist, K., 2000. Johan Hårleman, in: T. Andersson, T. Jonstoij, Tove \& K. Lundquist (eds), Svensk trädgårdskonst under 400 år. Stockholm: Byggförlaget, 62-71.

Magnusson, G., 2008. Bergslagen, in: U. Sporrong \& L. Wastesson (eds), Sveriges Nationalatlas Stockholm-Mälarregionen, Gävle: Kartförlaget, 61-66.

Mogren, M., 2009. Globalisering, plantager och landskapsförändringar i kolonialtidens Ceylon (Sri Lanka), in: M. Mogren, M. Roslund, B. Sundnér \& J. Wienberg (eds), Triangulering: historisk arkeologi vidgar fälten, Lund: Institutionen för arkeologi och antikens historia. Lunds Universitet, 173-203. Accessed 31 Oct 2018. http://lup-lub.se/record/1056483.

NitzeLius, T., 1962. Ekolsunds arboretum och barrträdskollektion. Lustgården: 5-56.

Noldus, B., 2005. Trade in good taste: relations in architecture and culture between the Dutch republic and the Baltic world in the Seventeenth Century. Zugl.: Diss. Utrecht univ., 2002.

Olausson, M., 1993. Den engelska parken i Sverige under gustaviansk tid. Diss. Uppsala: Univ.

Olausson, M., 1997. Trädgårdskonsten, in: G. Alm (ed.), Signums svenska konsthistoria (Bd 6) Barockens konst, Lund: Signum, 158-187.

Olausson, M., 2000. Tradition och förnyelse i trädgårdskonsten, in: M. Olausson \& R. Millhagen (eds), Carl Hårleman. Människan och verket. Stockholm: Byggförlaget, 126-145.

Riksantikvarieämbetet 16 Jan 1969. Accessed 15 Oct 2018. 
http://www.bebyggelseregistret.raa.se/bbr2/show/bilaga/showDokument. raa?dokumentId $=21000001823432 \&$ thumbnail $=$ false.

Riksarkivet (RA), Clas Totts samling E 5796.

Seton, B. G., 1941. The House of Seton. A study of lost causes. Edinburgh: Lindsay and Macleod. SöDerberg, B., 1967. Ekolsund, in: A. S. Svensson \& S. T. KJELlberG (eds), Slott och herresäten i Sverige: ett konst- och kulturbistoriskt samlingsverk. Uppland 1. Malmö: Allhem, 139-167.

Tнам, W., 1850. Beskrifning öfver Upsala län. Stockholm: Bagge.

UlRICH, L. \& E. UlRICH, 2016. Journaux personnels polyglottes des soeurs Ulrich tenus au Palais royal de Stockholm, à Djurgärden et dans la province, de 1830 à 1855. Choix et commentaires de Margareta Östman. Stockholm: Romanska och klassiska institutionen, Stockholms universitet. Accessed 31 Oct 2018. http://urn.kb.se/resolve?urn=urn:nbn:se:su:diva-139837.

UlväNG, G., 2017. Manor-house building and economic growth in Sweden in the eighteenth and nineteenth centuries, in: K. Heck, S. Bock \& J. Olschewski (eds), Schlösser und Herrenbäuser der Ostseeregion: Bausteine einer europässchen Kulturlandschaft. Schwerin: Thomas Helms Verlag, 41-68. 